\title{
Generoll Entomology \\ Incidence of potato green aphid and Liriomyza sp. in radish plants grown on different levels of organic fertilizer
}

\author{
Vinicius Borges $^{1 \bowtie \odot}$, Hozano de Souza Lemos Neto ${ }^{2 \oplus}$, \\ Jose Wagner da Silva Melo ${ }^{3 \oplus} \&$ Marcelo Almeida Guimarães ${ }^{4 \oplus}$
}

1. Escola Superior de Agricultura Luiz de Queiroz, Piracicaba, SP, Brasil. 2. Universidade Federal Rural do Semi-Árido, Mossoró, RN, Brazil. 3. Universidade Federal do Ceará, Fortaleza, CE, Brazil.

\section{EntomoBrasilis 14: e943 (2021)}

Edited by:
William Costa Rodrigues
Article History:
Received: 15. iii.2021
Accepted: $01 . v i .2021$
Published: $14 . v i .2021$
Corresponding author:
Vinicius Borges
Đ viniborrj@hotmail.com
Funding agencies:
\& Conselho Nacional de
Desenvolvimento Cientifico e
Tecnológico (CNPq)

Edited by:

William Costa Rodrigues

Article History:

Received: 15.iii.2021

Accepted: 01.vi.2021

Published: 14.vi.202

$\bowtie$ Corresponding author:

乃viniborrj@hotmail.com

Funding agencies:

Desenvolvimento Cientifico

Tecnológico $(\mathrm{CNPq})$

\begin{abstract}
Radish is a short cycle horticultural product from family Brassicaceae. Between the insects found on radish leaves, potato green aphid (Myzus persicae Sulzer) is one of the main pests of this culture, causing economic damage. Synthetic fertilizers used in conventional crops can promote changes in the pattern of amino acids in plants, leading to a higher insect damage. The source of fertilization is one of the factors that could influence in the incidence of pests. The objective of the study was to evaluate the incidence of potato green aphid and other pests on radish plants grown with different doses of organic fertilizer. The experiment was carried under semi-field conditions, in Fortaleza (Ceará State). A completely randomized design was used, with six replicates. The treatments consisted of five doses of organic compost $\left(0 ; 45 ; 60 ; 75 ; 90\right.$ t.ha-1 $\left.^{-1}\right)$. For the population survey of pests and natural enemies, counts were made in three evaluations (7, 14 and 21 days after sowing). The counting data were subjected to deviance analysis using a generalized linear model (GLM). It was observed significant differences in the number of adults $M$. persicae in the treatments of 75 and 90 t.ha-1. Presence of leafminer (Liriomyza sp.) was observed on plants without and with the lower doses of organic fertilizer. Even using organic fertilizers that promote a slower liberation of nutrients, high incidence of pests (Mainly M. persicae) was observed on radish plants.
\end{abstract}

Keywords: Agromizidae; Aphididae; Brassicaceae; Organic amendments; Raphanus sativus
De adish (Raphanus sativus L.) belongs to Brassicaceae family, and as other species also include in this botanic family, phytosanitary problems are constantly present (FILGUEIRA 2005). Among the arthropod pests that are associated with species of Brassicaceae in general, aphids are the most common insects found on leaves, causing economic damage (Carvalho et al. 2002; Van Emden \& Harrington 2007).

Aphids are reduced size arthropods, ranging in length from 1.5 to $2.5 \mathrm{~mm}$ (VAN EMden \& HarRington 2007). Usually, immigrant organisms are winged, in contrast to those who maintain the colony that do not have wings (BLACKMAN \& EASTOP 2000). There are both direct and indirect losses caused by the caused attack of this insect, the direct damage is associated to the feeding habit, while the indirect losses are attributed to liberation of honeydew, causing the grown of opportunist plant pathogens on the leaves (BAss et al. 2014).

The potato green aphid, Myzus persicae Sulzer (Hemiptera: Aphididae), is an polyphagous pest that cause significant economic damage in several crops (Bass et al. 2014). Approximately 400 species distributed in more than 40 botanical families are listed as hosts of the $M$. persicae (BLACKMAN \& EASTOP 2000). Its high capacity to adapt on different climatic conditions and, consequently, its wide distribution throughout the globe, makes the potato green aphid a severe pest, capable of transmitting more than 100 different types of viruses to plants (VAN EMDEN \& HARRINGTON 2007).

In tropical conditions, $M$. persicae reproduces by thelytokous parthenogenesis (BuENo 2005). Thus, females generate new

(c) The Author(s) 2021. Published by Entomologistas do Brasil

This article is published by Entomologistas do Brasil and licensed under Creative Commons Licence 4.0 (CC-BY) females in approximately 10 days, with the potential to generate approximately 80 individuals/female varying with the host plant and nutritional quality of the host (PETTERSON et al. 2007). In northeast of Brazil, the climatic conditions in addition to the biotic potential enhance infestations of $M$. persicae

VentuRA et al. (2008) found a correlation between the imbalance nutritional status of the plant and incidence of pest-arthropods. One of the reasons of nutritional imbalance could be related to the type of fertilization which the plant is subjected, wich can promote biochemical and physiological changes (AтіYen et al. 2000). Organic fertilizers benefit not only in plant growth, but also the edaphic fauna (including macro, meso and micro fauna), enhancing the biodiversity of beneficial organisms (Karbauskiene 2000; Berova \& Karanatsidis 2009). Synthetic fertilizers used in conventional crops can promote changes in the pattern of amino acids in plants, leading to a higher insect damage (Lockeretz et al. 1981; AltieRI 2003).

The objective of the study was to evaluate the incidence of potato green aphid and other pests on radish plants grown with different doses of organic fertilizer.

\section{MATERIAL AND METHODS}

The experiment was carried out in December 2016, under semi-field conditions, in Fortaleza (Ceará state, 0347' S and $38^{\circ} 30^{\prime} \mathrm{W}$ ). The location is classified as 'As' type, that is, Tropical with dry summer according to Köppen classification 
(Alvarez et al. 2014). During the experiment, the average of air temperature was $29^{\circ} \mathrm{C}$, with variation between $23.2^{\circ} \mathrm{C}$ and $31.8{ }^{\circ} \mathrm{C}$, at minimum and maximum, respectively. The accumulated rainfall in the period was $28.8 \mathrm{~mm}$.

A completely randomized design was used, with six replications, where each line with five plants was considered as one repetition. The treatments consisted of five doses of locally produced organic compost $\left(0 ; 45 ; 60 ; 75 ; 90\right.$ t.ha $\left.^{-1}\right)$. A mix of cattle manure and leaves of Anacardium occidentale L. (Plantae: Anacardiaceae) were used to make the compost, with the following chemical characteristics: $\mathrm{pH}\left(\mathrm{H}_{2} \mathrm{O}\right)=6.9$; $\mathrm{P}$ $\left(\mathrm{mg} / \mathrm{dm}^{3}\right)=368.7 ; \mathrm{K}\left(\mathrm{mg} / \mathrm{dm}^{3}\right)=2,300 ; \mathrm{Ca}\left(\mathrm{cmol}_{\mathrm{c}} / \mathrm{dm}^{3}\right)=10.9$; $\mathrm{Mg}\left(\mathrm{cmol} / \mathrm{dm}^{3}\right)=9.4 ; \mathrm{Zn}\left(\mathrm{mg} / \mathrm{dm}^{3}\right)=98 ; \mathrm{Fe}\left(\mathrm{mg} / \mathrm{dm}^{3}\right)=21.1 ;$ $\mathrm{Mn}\left(\mathrm{mg} / \mathrm{dm}^{3}\right)=67.7 ; \mathrm{Cu}\left(\mathrm{mg} / \mathrm{dm}^{3}\right)=0.7 ; \mathrm{B}\left(\mathrm{mg} / \mathrm{dm}^{3}\right)=1.6$. The organic fertilizer dosages established for each treatment were applied in three occasions, one in planting and the other two in coverage at 10 and 20 days after sowing (DAS). The compost was applied between the lines of cultivation. The experiment was conducted in $\mathrm{n}$ each experimental plot of $1 \mathrm{~m}^{2}(1.0 \times 1.0 \mathrm{~m})$, five longitudinal lines were allocated, using spacing of $0.20 \times 0.20 \mathrm{~m}$. The working area consisted on the three central lines. No chemical or alternative methods of pest control were used. Weed control was made by removing the plants manually. Sowing was carried out with radish seeds of the cultivar 'Cometo' Top Seed ${ }^{\circledR}$. Irrigations were made three times a day with micro sprinkler $(60 \mathrm{~L} / \mathrm{h})$, aiming to replace the soil moisture lost by potential evapotranspiration throughout the day.

For the population survey of pests, counts were made in three evaluations (7, 14 and 21 days after sowing), for this, a fully expanded leaf was analyzed in each of the plants present in the three central lines of each plot, totaling 15 plants evaluated per treatment. Only adults were considered in the count to provide a better perception of population growth, taking in consideration that not all nymphs reach adult stage. The evaluations were made in one cycle of radish production. The counting data were subjected to deviance analysis using a generalized linear model (GLM), the means being compared by the Tukey test $(p=0.05)$ using the software SAS (SAS INSTITUTE 2002). A pearson's correlation study between the presence of $M$. persicae and other pests was also performed.

\section{RESULTS AND DISCUSSION}

The potato green aphid was already present at the first evaluation (7 DAS), but no significant effect of the treatments on the number of adults of $M$. persicae was found (Table 1 ). Only at 21 DAS the average adult density of $M$. persicae in the plants was statistically significant. The organic fertilizer doses of 75 and 90 t.ha $^{-1}$ provided the greatest infestations of green aphids.

The incidence of leafminer fly Liriomyza sp. (Diptera: Agromizidae) was also observed in $R$. sativus. Plants that did not receive organic fertilizer were more attacked by leaminers, with about 33\% of plants infested. A negative correlation between the incidence of $M$. persicae and Liriomyza sp. was obtained by the Pearson's correlation coefficient (-0.88). Possibly, this fact may be related to a competition between these pest arthropods on the host. No natural enemies associated with $M$. persicae or Liriomyza sp. were found in the evaluations.

Due to the absence of tactics for control potato green aphid on the plants, the infestation possibly started in the first days after germination, with the arrival of winged females to start the colony. In case of plants from Brassicaceae family, the glycosinolate sinigrine, substance naturally produced by several species of Brassicaceae, favors the host's encounter by aphids (Nault \& Styer 1972; Pinchersky \& Gershenzon 2002).

The period of nymph-adult of $M$. persicae on $R$. sativus is about 13 days (Hong et al. 2019). Therefore, estimating the beginning of the infestation close to 7 DAS, a significant increase in the population would only be achieved at least 17 DAS without presume possible arrivals of other winged forms attracted by intraspecific communication chemicals. It was observed that in Rhopalosiphum padi L. (Hemiptera: Aphididae) winged females are attracted by aggregation pheromones released by other winged females already present in the host plant (PICKETT \& GLINwOOd 2007). Therefore, both the generation time and intra-specific communication between individuals may have led to a greater abundance of $M$. persicae, resulting in a significant difference both between treatments and in relation to the evaluation dates at 21 DAS.

In a study made by MichelotTo et al. (2005) it was verified that at a temperature of $30{ }^{\circ} \mathrm{C}$, there was no reproduction of $M$. persicae in eggplant (Solanum melogena L.) as host. The temperature values during the experiment period were always close to $30^{\circ} \mathrm{C}$, with an increase on pest population over time. The divergences in terms of the results obtained in the present study in comparison to MichelotTo et al. (2005) may come from both the difference in relation to the host plant and population of $M$. persicae.

Plants submitted to the highest doses of organic fertilizer showed the highest levels of infestation by M. persicae but no incidence of other pests. The greater availability of nutrients for plants may have generated a higher concentration of free amino acids, providing greater nutritional quality for the green aphid, thus contributing to its population increase. In general, free amino acids directly favor the development of the green aphid, which reduces its generation time and, consequently, increases its speed of plant colonization (BORTol et al. 2005).

In organic production systems, where soil fertilization is made with organic amendments, the availability of nutrients for plants can be considered as slower compared to synthetic fertilizers. However, according to the results obtained in the study, higher doses of organic fertilizers promote higher incidence of $M$. persicae in radish plants. Further research must be done with more cycles of production of radish to reinforce the results obtained.

Table 1. Averages of adults of Myzus persicae (Hemiptera: Aphididae) and incidence of Liriomyza sp. (Diptera: Agromizidae) at 7, 14 e 21 days after sowing (DAS) in radish plants submited to different levels of organic fertilizer.

\begin{tabular}{lllll}
\hline Doses (t.ha-1) & 7 DAS & 14 DAS & 21 DAS & Liriomyza sp. \\
\hline 0 & $0.4 \pm 0.42 \mathrm{Aa}$ & $5.1 \pm 2.67 \mathrm{Aa}$ & $21.5 \pm 4.21 \mathrm{Ab}$ & Present \\
45 & $0.3 \pm 0.19 \mathrm{Aa}$ & $2.8 \pm 1.13 \mathrm{Aa}$ & $24.1 \pm 9.42 \mathrm{Ab}$ & Present \\
60 & $0.4 \pm 0.29 \mathrm{Aa}$ & $7.1 \pm 2.86 \mathrm{Aa}$ & $20.9 \pm 10.21 \mathrm{Ab}$ & Absent \\
75 & $1.4 \pm 0.75 \mathrm{Ba}$ & $6.9 \pm 2.17 \mathrm{Ba}$ & $60.1 \pm 10.81 \mathrm{Aa}$ & Absent \\
90 & $2.5 \pm 0.88 \mathrm{Ba}$ & $16.1 \pm 3.50 \mathrm{Ba}$ & $74.3 \pm 12.48 \mathrm{Aa}$ & Absent \\
\hline
\end{tabular}

Lower case letters compare columns and upper case letters compare lines. Means followed by the same letter do not differ statistically by the Tukey test at the $5 \%$ level of significance. 


\section{ACNOWLEDGMENTS}

To Conselho Nacional de Desenvolvimento Cientifico e Tecnológico (CNPq) for the financial support.

\section{REFERENCES}

Altieri, MA \& Cl Nicholls, 2003. Soil fertility management and insect pests: harmonizing soil and plant health in agroecosystems. Soil \& Tillage research, 72: 203-2011. DOI: https://doi.org/10.1016/S0167-1987(03)00089-8.

Alvarez, CA, JL Stape, PC Sentelhas, JLM Gonçalves \& G Sparovek, 2014. Koppens's climate classification map for Brazil. Meteorologische Zeitschrift, 22: 711-728. DOI: https://doi.org/10.1127/0941-2948/2013/0507

Atiyeh, R, C Edwards, S Subler \& J Metzger, 2000. Pig manure vermicompost as a component of a horticultural bedding plant medium: effects on physicochemical properties and plant growth, Bioresource technology, 78: 11-20. DOI: https://doi.org/10.1016/S0960-8524(00)00172-3

Bass, C, AMP Puinean, CT Zimmer, I Denholm, LM Field, SP Foster, O Gutbrod, R Nauen, R Slater \& MS Williamson, 2014. The evolution of insecticide resistance in the peach potato aphid, Myzus persicae. Insect Biochemistry and Molecular Biology, 51: 41-51. DOI: https://doi.org/10.1016/j.ibmb.2014.05.003

Berova M \& G Karanatsidis, 2009. Physiological response and yield of pepper plants (Capsicum annum L.) to organic fertilization. Journal of Central European Agriculture, 9: 715-721.

Blackman, RL \& VF Eastop, 2000. Aphids on the world's cops: identification and information Guide. 2nd Ed. Chichester, John Wiley \& Sons Ltd.

Bortoli, AS, HOS Dória, NMMS Alberaria \& MV Botti, 2005. Aspectos Biológicos e dano de Diartea saccharalis (Fabr., 1794) (Lepidoptera: Pyralidae) em Sorgo cultivado Sob diferentes doses de nitrogênio e potássio. Ciência e Agrotecnologia, 29:267-273. DOI: https://doi.org/10.1590/ S1413-70542005000200001

Bueno, VHP, 2005. Controle biológico de pulgões ou afídeos-praga em cultivos protegidos: Pragas em cultivo protegido e controle biológico. Informe Agropecuário, 26: 9-17, 2005.

Carvalho, L, VHO Bueno \& RP Martinez, 2002. Levantamento de afídeos alados em plantas hortícolas em Lavras-MG. Ciência e Agrotecnologia, 26: 523-532.
Filgueira, FAR, 2005. Novo manual de olericultura: a agrotecnologia moderna na produção e comercialização de hortaliças. 2nd Ed. Viçosa, UFV.

Hong, F, HL Han, P Pu, D Wei, J Wang \& Y Liu, 2019. Effects of five host plant species on the life history and population growth parameters of Myzus persicae (Hemiptera: Aphididae). Journal of Insect Science, 19: 1-8. DOI: https://doi.org/10.1093/jisesa/iez094

Karbauskiene, E, 2000. The influence of organic fertilizers on microorganisms in tomato rhizosphere, Horticulture and vegetable growing (Lithuania). Scientific works, 19: 122133.

Lockeretz, W, G Shearer \& DH Kohl, 1981. Organic farming in the corn belt. Science, 211: 540-546. DOI: https://doi.org/10.1126/science.211.4482.540

Michelotto, MD, NR Chagas Filho, RA Silva \& AC Busoli, 2005. Longevidade e parâmetros reprodutivos de Myzus persicae (Sulzer, 1776) (Hemiptera: Aphididae) sobre berinjela em diferentes temperaturas. Ciência Rural, 35: 788-793. https://doi.org/10.1590/S0103-84782005000400006

Nault, LR \& WE Styer, 1972. Effects of sinigrin on host selection by aphids. Entomologia Experimentalis et Applicata, 15: 423-437. DOI: https://doi.org/10.1111/j.1570-7458.1972. tb00230.x

Petterson, J, WF Tjallingii \& J Hardie, 2007. Host-plant selection and feeding, pp. 87 - 113. In: Van Emden, HF \& $\mathrm{R}$ Harrington. Aphids as crop pests. Wallingford, CABI international.

Pichersky, E \& J Gershenzon, 2002. The formation and function of plant volatiles: perfumes for pollinator attraction and defense. Current Opinion in Plant Biology, 5: 237-243. DOI: https://doi.org/10.1016/S1369-5266(02)00251-0

Pickett, JA \& RT Glinwood, 2007. Chemical Ecology, pp. 235254. In: Van Emden, HF \& R Harrington. Aphids as crop pests. Wallingford, $C A B I$ international.

SAS Institute, 2002. SAS/STAT software, version 9.1. SAS Institute Inc., Cary, NC.

Van Emden, HF \& R Harrington, 2007. Aphids as crop pests. Wallingford, CABI international.

Ventura, SRS, AG Carvalho \& FT Pereira, 2008. Efeito da adubação na população de Corythaica cyathicollis em berinjela, em função do período de coleta. Revista Biotemas, 21: 47-51. DOI: https://doi.org/10.5007/21757925.2008v21n1p47

$* * * * * * * * * *$

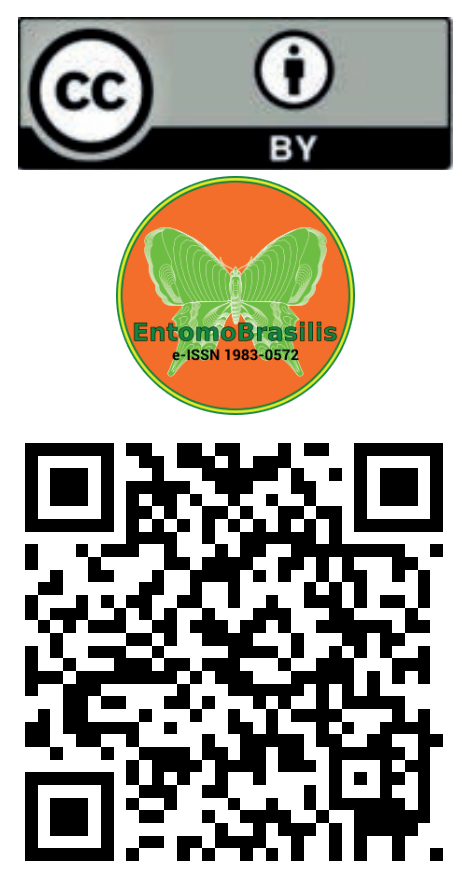

